\title{
BIBLIOGRAPHIES OF SCHOLARS: RESOURCES OF TYNDALE IIBRARY
}

\section{Compiled by Colin J. Hemer}

The following list indexes bibliographies of the writings of individual scholars, as collected from Festschriften, journals and other occasional published or unpublished sources. All the items listed are permanently accessible in Tyndale Library, Cambridge, and focus upon Biblical and related studies, in which the Library specializes. It is not possible to make exhaustive search, and there are doubtless omissions, but it is hoped that this list will be a useful tool for Biblical and theological research.

For the New Testament the reader is referred also to J. C. Hurd's valuable Bibliography of New Testament Bibliographies (Seabury Press: New York, 1966), which includes a biographical section on individual scholars and gives notice of bibliographies of some of these. Many of his entries refer to biographies or older issues of journals than are held here: such are the important bıbliographies of $\mathrm{W}$. Bauer, Behm, Dibelius (supplementary), Kittel, Klostermann, Schniewind and Windisch in TLZ. But the large majority even of New Testament items here is not in Hurd: there has been a proliferation of Festschriften in the last fifteen years, and most of them list publications. Inevitably, many famous names are still unrepresented, and scholars of earlier generations predominate where current work is not yet listed.

It may normally be taken that the listings cited are substantially complete at least for the scholar's technical books and articles. Arrangement is usually either chronological by years or classified by type, subject or journal. Some items are fragmentary or supplementary, selective or otherwise limited, or omit reviews. A few of the most comprehensive are elaborately indexed. Notes on such points are appended where the information is not apparent and may assist or caution the researcher. Sometimes, where our entry only supplements an earlier bibliography not held in the library, I have added brief parenthetic reference 
to the earlier publication and verified it elsewhere, for fragmentary allusion to a mere appendage will unnecessarily frustrate rather than serve the researcher. I have occasionally chosen to omit a brief item which adds nothing of consequence to the documentation of the scholar.

ABBOTT: Miroslav Krek, 'Nabia Abbott's Published Works:

A Chronological Bibliography', JNES 40 (1981) 165172.

ADCOCK: 'Bibliography of the Published Writings of Sir Frank Adcock', JRS 56 (1966) xiii-xv Ichronol., not reviews].

ALAND: Beate Köster and Christian Uhlig, 'Bibliographie Kurt Aland', Text-Wort-Glaube. Studien zur Überlieferung, Interpretation und Autorisierung biblischer Texte Kurt Aland gewidmet, ed. Martin Brecht (Berlin: de Gruyter, 1980) 377-397 [chronol.].

ALBRIGHT: (1) 'Bibliography of W. F. Albright (from 1911 through May, 1958)', The Bible and the Ancient Near East. Essays in honor of William Foxwell Albright, ed. G. Ernest Wright (London: Routledge and Kegan Paul, 1961) 363-389 [chronol.].

(2) David Noel Freedman, 'Bibliography of W. F. Albright', W. F. Albright Volume (Eretz-Israel Archaeological, Historical and Geographical studies 9), ed. A. Malamat (Jerusalem: Israel Exploration Society, 1969) 1-5 [chronol., 1958-1968].

(3) David Noel Freedman, The Published Works of William Foxwell Albright: A Comprehensive Bibliography (Cambridge, Mass.: American Schools of Oriental Research, 1975), xvi + 226 pp. [classified and indexed].

ALLEMAN: Jacob M. Myers, 'Bibliography of the Writings of Herbert C. Alleman', Biblical Studies in Memory of H.C. Alleman, ed. J. M. Myers, O. Reimherr and H. N. Bream (Locust Valley, New York: J. J. Augustin, 1960) 63-66 [classif.].

ANDERSON, G. W.: 'A Select Bibliography of the Publications of G. W. Anderson', VT 32 (1982) 125128 [not reviews].

ANDRESEN: 'Bibliographie Carl Andresen', TLZ 104

(1979) 539-541 Iclassif., reviews not detailed]. 
AP-THOMAS: 'Cyhoeddiadau D. R. Ap-Thomas', Efrydiau Beiblaidd Bangor II. Cyfrol Deyrnged $i$ Dafydd $R$. ApThomas, ed. Gwilym H. Jones (Abertawe ISwansea] : John Penry, 1977) xi-xiii [chronol., not reviews].

AVI-YONAH: Milka Cassuto Salzmann, 'Bibliography of M. Avi-Yonah', IEJ 24 (1974) 278-315 Ichronol., indexed].

BARCLAY: 'Books by William Barclay', Biblical studies in Honour of William Barclay, ed. Johnston R. McKay and James F. Millex (London: Collins, 1976) 221-223 [books only].

BARDTKE: (1) Dietmar Mathias, 'Bibliographie Hans Bardtke', TLZ 96 (1971) 716-720 Iclassif., cf. TLZ 91 (1966) 709-716].

(2) D. Mathias, 'Bibliographie Hans Bardtke (22.9.1906-8.3.1975)', TLZ 102 (1977) 155-160 [suppl., classif.].

BARR: 'Select Bibliography. Works by James Barr', Paul R. Wells, James Barr and the Bible. Critique of a New Liberalism (Phillipsburg, New Jersey:

Presbyterian and Reformed Publishing, 1980) 380-384.

BARTH: 'Works by Karl Barth', G. W. Bromiley in Creative Minds in Contemporary Theology, ed. Philip Edgcumbe Eughes (Grand Rapids: Eerdmans, 1966) 60-62 [books, alphab.].

BAUERNFEIND: 'Bibliographie der Schriften von otto Bauernfeind', Otto Bauernfeind, Kommentar und Studien zur Apostelgesuhichte, ed. Volker Metelmann (Tübingen: J. C. B. Mohr, 1980) 487-491 [classif.] .

BAUMGARTNER: 'Bibliographie', Walter Baumgartner, Zum Alten Testament und seiner Umwelt. Ausgewähıte Aufsätze (Leiden: Bri.1, 1959) 1-26 [chronol.].

BAUR: 'Bibliography. Ferdinand Christian Baur', Horton Harris, The Tübingen School (Oxford: Clarendon Press, 1975) 263-274 [chronol., ref. to MSS and letters].

BEEK: 'Publicationc by Professor Tr. M. A. Beek in the Period 1935-1973', Travels in the World of the old Testament. Studies presented to Professor M. A. Beek on the occasion of his 65th birthday, ed. M. S. H. G. Heerma van Voss, Ph. H. J. Houvink ten Cate and N. A. van Uchelen (Assen: van Gorcum, 1974) xiil-xviii [classif., not reviews]. 
BENTZEN: 'Bibliography of Aage Bentzen', Congress Volume, Copenhagen 1953 (VT Suppl. I) Leiden: Brill, 1953) ix-xv [classif.].

BERKOUWER: (1) M. J. Arntzen, 'Bibliografie', Ex Auditu Verbi. Theologische opstellen aangeboden aan Prof. Dr. G. C. Berkouwer (Kampen: J. H. Kok, 1965) 327332 [classif., not reviews].

Smedes in Creative Minds in Contemporary Theology, ed. P. E. Hughes (Grand Rapids: Eerdmans, 1966) 96-97 [classif., mainly books] .

BERTHOLET: Verena Tamann-Bertholet, 'Bibliographie A. Bertholet', Festschrift Alfred Bertholet zum 80 . Geburtstag, ed. Walter Baumgartner, Otto Eissfeldt, Karl Elliger and Leonhard Rost (Tübingen: J. C. B. Mohr, .1950) 564-578 [classif.].

BLACK: (1) 'A Bibliography of the Published Writings of Matthew Black', Neotestamentica et Semitica. Essays in Honour of Matthew Black, ed. E. E. Ellis and Max Wilcox (Edinburgh: T. and T. Clark, 1969) ix-xv [chronol., not reviews].

(2) M. C. Blackwood, 'Bibliography of Matthew Black', Text and Interpretation. Studies in the New Testament Presented to Matthew Black, ed. E. Best and R. MCL. Wilson (Cambridge UP, 1979) [1968-1977 and suppl., not reviews].

BONNARD: 'Bibliographie de Pierre Bonnard', Anamnesis. Recherches sur le Nouveau Testament. Hommage du Doyen Samuel Amsler (Cahiers de la Revue de Théologie et de Philosophie 3) (Genève, Lausanne and Neuchâtel: Société Académique Vaudoise, 1980) 219222 [classif., not reviews].

BRILIING: 'Bibliographie Bernhard Brilling (Fortsetzung) 1968-1978', Theokratia. Jahrbuch des Institutum Judaicum Delitzschianum 3 (1973-1975). Festgabe für Harald Koch zum 70. Geburtstag, ed. K. H. Rengstorf (Leiden: Brill, 1979) 263-270 [classif. Cf. Theokratia 1 (1967-1969), ed. Rengstorf (Leiden, 1970) 195-223].

BRONGERS: 'Bibliografie van de voornaamste geschriften van Dr. H. A. Brongers', Vruchten van de uithof. Studies opgedragen aan dr. H. A. Brongers, ed. A. R. Hulst (Utrecht: Theologisch Instituut, 1974) 5-6 [chronol., select]. 
BRUCE: (1) W. W. Gasque, 'A Select Bibliography of the Writings of F. F. Bruce", Apostolic History and the Gospel. Biblical and Historical Essays presented to F. F. Bruce on his 60th Birthday, ed. W. Ward Gasque and Ralph P. Martin (Exeter: Paternoster, 1970) 21-34 [chronol., not reviews].

(2) W. W. Gasque, 'A Supplementary Bibliography of the Writings of F. F. Bruce', Journal of the Christian Brethren Research Fellowship 22 (November 1971) 21-47 [additions and reviews].

(3) W. W. Gasque, 'A Select Bibliography of the Writings of F. F. Bruce 1970-1979', Pauline Studies. Essays presented to Professor F. F. Bruce on his 7oth Birthday, ed. Donald A. Hagner and Murray J. Harris (Exeter: Paternoster, 1980) xxii-xxxvi [chronol.].

BRUNNER, E.: 'Works by Emil Brunner', Paul G. Schrotenboer in Creative Minds in Contemporary Theology, ed. P. E. Hughes (Grand Rapids: Eerdmans, 1966) 128-130 [select, chronol.].

BRUNNER; P.: Albrecht Peters, 'Fortsetzung der Bibliographie Peter Brunner', TLZ 96 (1971) 238-240 [classif., cf. Auferbauung des Leibes Christi. Festgabe für D. Peter Brunner zum 65. Geburtstag, ed. E. Schlink and A. Peters, Kassel, 1965, 295-304].

BUCKLER: Georgina Buckler, 'A List of the Published Writings of William Hepburn Buckler', Anatolian Studies Presented to William Hepburn Buckler, ed. W. M. Calder and Josef Keil (Manchester UP, 1939) xiii-xviii [chronol.].

BULTMANN: (1) 'Bibliographia Dibeliana atque Bultmanniana', Coniectanea Neotestamentica 8 (1944) 23-35 [chronol.].

(2) 'Bibliography', Existence and Faith. Shorter Writings of Rudolf. Bultmann, $t x$. and ed. Schubert M. Ogden (London: Hodder and Stoughton, 1961) 317-319 [select, classif.].

(3) 'Bibliography of the Publications of Rudolf Bultmann to 1965', The Theology of Rudolf Bultmann, ed. C. W. Kegley (London: SCM, 1966) 289310 [chronol.].

(4) 'Bibliography', Walter Schmithals, An Introduction to the Theology of Rudolf Bultmann, tr. J. Bowden (London: SCM, 1968) 325-328 Ichronol., select]. 
BURKITT: 'Professor Burkitt's Writings', JTS 36 (1935) 337-346 [classif.].

BURROWS: J. Philip Hyatt and Raymond P. Morris,

'Bibliography of Millar Burrows' Works'; VT 9 (1959)

423-432 [classif.], reprinted in Essays in Honour of Millar Burrows (Leiden: Brill, 1959) 87-96.

CASE: Allen Cabaniss, 'Bibliography of the Writings of Shirley Jackson Case', Envirommental Factors in Christian History, ed. John Thomas McNeill, Matthew Spinka and Harold R. Willoughby (Chicago UP, 1939) 399-407 [classif.].

CASEY: 'Bibliography of Robert Pierce Casey', Biblical and Patristic Studies in Memory of Robert Pierce Casey, ed. J. Neville Birdsall and Robert W. Thomson (Freiburg etc.: Herder, 1963) 265-269. [chronol., not reviews] .

CAŹELLES: Joseph Trinquet, 'Bibliographie de Monsieur Henri Cazelles', De la Tôrah au Messie. Mélanges Henri Cazelles, ed. J. Doré, P. Grelot, M. Carrez (Paris: Desclée, 1981) 15-43 [chronol.].

COLWELL: Irving Alan -parks, 'Bibliography of Ernest Cadman Colwell', Jesus and the Historian. Written in Honor of Ernest Cadman Colwell, ed. F. Thomas Trotter (Philadelphia: Westminster Press, 1968) 151-173 [classif.].

CONZELMANN: Wolfgang Hinze and Andreas Lindemann, 'Veröffentlichungen von Hans Conzelmann', Jesus Christus in Historie und Theologie. Neutestamentliche Festschrift für Hans Conzelmann zum 60. Geburtstag, ed. Georg Strecker (Tübingen, J. C. B. Mohr, 1975) 549-557 [chronol..].

COOK: D. Winton Thomas, 'Select Bibliography of the Writings of Stanley Arthur Cook', Essays and Studies Presented to Stanley Arthur Cook in Celebration of his seventy-fifth birthday, ed. D. Winton Thomas (London: Taylor's Foreign Press, 1950) 1-13 [chronol., incl. some reviews].

CULIMANN: (1) W. Rordorf, 'Bibliographia Cullmanniana', Neotestamentica et Patristica. Eine Freundesgabe, Herrn Professor Dr. Oscar Cullmann zu seinem 60. Geburtstag überreicht (NovT Suppl. 6) (Leiden: Brill, 1962l ix-xix [chronol.]. 
CULLMANN: (2) 'Buchveröffentlichungen', Oscar Cullmann, Vorträge und Aufsätze.1925-1962, ed. Karlfried Fröhlich (Tl̋bingen: J. C. B. Mohr, 1966) 694.

(3) 'Works by Oscar Cullmann', David $\mathrm{H}$. Wallace in Creative Minds in Contemporary Theology, ed. P. E. Hughes (Gra.nd Rapids: Eerdmans, 1966) 198-202 [select, chronol.].

(4) Heiko Heck, 'Bibliographia Cullmanniana 1962-1971', Neues Testament und Geschichte.

Historisches Geschehen und Deutung im Neuen Testament, Oscar Cullmann zum 70. Geburtstag, ed. Heinrich Baltensweiler and Bo Reicke (Zurich: Theologischer Verlag and Tübingen: J. C. B. Mohr, 1972) 329-344 [additions and chronol.].

CURRIE: 'Written Works by Stuart Dickson Currie', Texts and Testaments. Critical Essays on the Bible and Early Church Fathers. A Volume in honor of stuart Dickson Currie, ed. W. Eugene March (San Antonio: Trinity University Press, 1980) 301-302 [classif., not reviews].

DAHL: Halvor Moxnes, 'Nils Alstrup Dahl. A select bibliography 1936-1974', God's Christ and His People. Studies in Honour of Nils Alstrup Dahl, ed. Jacob Jervell and Wayne A. Meeks (Oslo, Bergen and Tromso: Universitetsforlaget, 1977) 11-17 [chronol., incl. major reviews].

DAUBE: B. Jackson and Peter Stein, 'Bibliographia Daubeana', Donum Gentilicium. New Testament Studies in Honour of David Daube, ed. E. Bammel, C. K. Barrett and W. D. Davies (Oxford: Clarendon Press, 1978) 307-317 [chronol., not reviews].

DAVIES, G. HENTON: 'A Bibliography of the Writings of Gwynne Henton Davies', Proclamation and Presence. old Testament Essays in Honour of Gaynne Henton Davies, ed. John I. Durham and J. R. Porter (London: SCM, 1970) xviii-xx [chronol., not reviews].

DAVIES, W. D.: 'Bibliography of the Works of W. D. Davies', Jews, Greeks and Christians. Religious Cultures in Late Antiquity. Essays in Honor of William David Davies, ed. Robert Hamerton-Kelly and Robin Scroggs (Leiden: Brill, 1976) 1-10 [chronol.].

DAWSON: Claude Locas, 'Christopher Dawson: A Bibliography', HTR 66 (1973) 177-206 [classif.]. 
DE BOER: 'A Select Bibliography of the Publications of R. A. H. de Boer'; VT 30 (1980) 513-517 [chronol.].

DEHN: Henning Theurich, 'Bibliographie Günther Dehn', TLZ 97 (1972) 391-397 Iclassif.].

DELLING: (1) Malwine Maser, 'Bibliographie Gerhard Delling', TLZ 100 (1975) 398-400 Iclassif., not reviews; cf. TLZ 90 (1965) 555-558; 95 (1970) 628].

(2) Helgard Steinacker, 'Bibliographie Gerhard Delling', TLZ 105 (1980) 397-400 Iclassif., list of journals containing his reviews].

DEN BOER: 'Bibliography', $\mathbf{w}$. den Boer, EYTГPAMMATA. Studies in Graeco-Roman History, ed. H. W. Pleket, H. S. Versnel and M. A. Wes (Leiden: Brill, 1979) ix-xxviii [chronol.].

JENNEY: (1) 'The Works of James Denney', John Randolph Taylor, God Loves Like That! The Theology of James Denney (London: SCM, 1962) 191-196 [classif., not reviews].

(2) 'Works by James Denney', I. Howard Marshall in Creative Minds in Contemporary Theology, ed. P. E. Hughes (Grand Rapids: Eerdmans, 1966) 237 [select].

DE ZWAAN: 'Bibliografie van Prof. Dr. J. de Zwaan', Studia Paulina in honorem Johannis de Zwaan septuagenarii, ed. J. N. Sevenster and W. C. van Unnik (Haarlem: de Erven F. Bohn, 1953) 235-245 [classif., not reviews].

DHORME: 'Bibliographie', Recueil Édouard Dhorme. Études bibliques et orientales (Paris: Imprimerie Nationale, 1951) i-xvi [classif.].

DIBELIUS: 'Bibliographia Dibeliana atque Bultmanniana' Coniectanea Neotestamentica 8 (1944) 1-22 [classif.].

DINKLER: Jens W. Taeger, 'Bibliographie Erich Dinkler 1932-1979', Theologia Crucis - Signum Crucis. Festschrift für Erich Dinkler zum 70. Geburtstag, ed. Carl Andresen and Günter Klein (Tübingen: J. C. B. Mohr, 1979) 551-563 [chronol.].

DODD: (1) 'Bibliography of the Works of Charles Harold Dodd', The Background of the New Testament and its Eschatology. In Honour of Charles Harold Dodd, ed. W. D. Davies and D. Daube (Cambridge UP, 1956) xiii-xviii [chronol., some reviews]. 
DODD: (2) 'Works by C. H. Dodd', F. F. Bruce in Creative Minds in Contemporary Theology, ed. P. E. Hughes (Grand Rapids: Eerdmans, 1966) 268-269 Iselect, chronol.].

-: (3) 'Bibliography', F. W. Dillistone, C. H. Dodd. Interpreter of the New Testament (Grand Rapids: Eerdmans, 1977) 249-251 Ichronol., select, from 1954, not reviews].

DOOYEWEERD: 'Works by Herman Dooyeweerd', William Young in Creative Minds in Contemporary Theology, ed. P. E. Hughes (Grand Rapids: Eerdmans, 1966) 302-304 [select, chronol.].

DÖRRIES: Ernst Berneburg, 'Bibliographie Hermann Dörries', TLZ 100 (1975) 877-878 [classif., cf. TLZ 86 (1961) 471-474].

DRIVER, G. R.: (1) 'Select Bibliography of the Writings of Godfrey Rolles Driver', Hebrew and Semitic Studies Presented to Godfrey Rolles Driver in celebration of his seventieth birthday, ed. D. Winton Thomas and W. D. McHardy (Oxford: Clarendon Press, 1963) 191-206 [chronol.].

(2) J. A. Emerton, 'A List of G. R. Driver's Publications since 1962', VT 30 (1980) 185191.

DUPONT-SOMMER: Hélène Lozaghmeur, 'Publications de M. André Dupont-Sommer', Hommages a André Dupont-Sommer, ed. A. Caquot and M. Philonenko (Paris: AdrienMaisonneuve, 1971) 539-556 [classif.].

EDEL: 'Bibliographie Elmar Edel', Festschrift Elmar Edel, ed. Manfred Görg and Edgar Pusch (Bamberg, 1979) 1-12 [chronol.].

EICHRODT: (1) Ernst Jenni, 'Die gedruckten Veröffentlichungen Walther Eichrodts', Festgabe für Walther Eichrodt zum 70. Geburtstag, TZ 16 (1960), 354-358 [chronol.; reviews summarised].

(2) 'Bibliographie Walter Eichrodt

(† 20.5.78). Veröffentlichungen seit 1970', TLZ 103 (1978) 544 [Cf. TLZ 85 (1960) 629-634; 95 (1970) 955958].

EISSFELDT: Karl-Martin Beyse, 'Verzeichnis der Schriften von Otto Eissfeldt', O. Eissfeldt, Kleine Schriften, Vol. 5, ed. R. Sellheim and Fritz Maass (Trubingen: J. C. B. Mohr, 1973) 222-287 [chronol.]. 
ELLIGER: D. Kellermann, 'Bibliographie Karl Elliger für Jahre 1966ff', Wort und Geschichte. Festschrift für

Karl Elliger zum 70. Geburtstag, ed. Hartmut Gese and Hans Peter Rüger (AOAT 18) (Neukirchen-Vluyn: Neukirchener Verlag, 1973) 209-211 [classif., cf. Theologische Bücherei 32 (1966) 260-264].

ELLWEIN: A. Strobel, 'Bibliographie Eduard Ellwein', TLZ 100 (1975) 552-555 Iclassif., not reviews].

FASCHER: Joachim Rohde, 'Bibliographie Erich Fascher', TLZ 98 (1.973) 78-80 [classif., cf. TLZ 82 (1957) 949$954 ; 92$ (1967) 955-960].

FOHRER: 'List of Professor Georg Fohrer's Publications', Prophecy. Essays presented to Georg Fohrer on his sixty-fifth birthday, ed. J. A. Emerton (Berlin and New York: de Gruyter, 1980) 192-202 [classif., his 2765 reviews and notices not included].

FORSYTH: 'Selected Works by P. T. Forsyth', Samuel J. Mikolaski ir. Creative Minds in Contemporary Theology, ed. P. E. Hughes (Grand Rapids: Eerdmans, 1966) 338339.

FRIDRICHSEN: W. Bauer, 'Zur Erinnerung an Anton Fridrichsen', ZNTW 45 (1954) 123-129 [including mention of his principal writings].

FRIEDRICH: H. Hammerich and H. Mahnke, 'Bibliographie G. Friedrich', Die Wort und die Wörter, Festschrift Gerhard Friedrich zum 65. Geburtstag, ed. Horst Balz and Siegfried Schulz (Stuttgart, Berlin, Köln and Mainz: Kohlhammer, 1973) 231-235 [chronol.].

FUCHS: Johannes B. Brantschen, 'Bibliographie Ernst Fuchs', TLZ 98 (1973) 633-638 [classif.].

FURLANI: Silvic Furlani, 'Bibliografia degli scritti di Giuseppe Furlani dal 1914 a tutto il 1956', Scritti in onore di Giuseppe Furlani, 2 vols., ed. Giovanni Bardi (Roma: Istituto di Studi orientali della Università di Roma, 1957) xiii-xxxvii [chronol.].

GADD: A. R. M(illard), 'A Bibliography of C. J. Gadd', Iraq 31 (1969) 184-188 [classif., not reviews].

GALLING: Peter Welten, 'Bibliographie Kurt Galling', Archäologie und Altes Testament. Festschrift für Kurt Galling, ed. A. Kuschke and E. Kutsch (Tübingen: J. C. B. Mohr, 1970) 333-347 [classif.]. 
GASTER: 'Theodore Gaster Bibliography', The Gaster Festschrift (Journal of the Ancient Near Eastern Society of Columbia University 5, 1973) 445-453 [select, classif., not reviews].

GELB: John L. Hayes, 'Bibliography of the works of I. J. Gelb', Approaches to the Study of the Ancient Near East. A Volume of Studies Offered to Ignace Jay Gelb on the Occasion of his 65th Birthday (Orientalia 42, 1973, Fasc. 1-2) ed. Giorgio Buccellati (Rome: Biblical Institute Press, 1973) 1-8 [classif.].

GELIN: Raymond Etaix, 'Bibliographie de Monsieur Albert Gelin', À la Rencontre de Dieu. Mémorial Albert Gelin, ed. A. Barucq, J. Duplacy, A. George and H. de Lubac (Le Puy, Lyon and Paris: Editions Xavier Mappus, 1961) 23-39 [classif.].

GERLEMAN: Eva Strömberg, 'Bibliographie Gillis Gerleman 1942-1977', Annual of the Swedish Theological Institute 11 (1978) 147-155 [chronol.].

GINGRICH: 'Published Books and Articles. Publications by F. W. Gingrich', Festschrift to Honor F. Wilbur Gingrich, ed. Eugene H. Barth and R. E. Cocroft (Leiden: Brill, 1972) 8-15 [classif.].

GINSBERG: J. H. Tigay, 'Bibliography of H. L. Ginsberg's Writings', H. L. Ginsberg Volume (Eretz-Israel. - Archaeological, Historical and Geographical Studies 14), ed. Menahem Haran (Jerusalem: Israel Exploration Society, 1978) $\tau \supset-\lambda$ ? [chronol., with subject index].

GLUECK: Eleanor K. Vogel, 'Bibliography of Nelson Glueck', Near Eastern Archaeology in the Twentieth Century. Essays in Honor of Nelson Glueck, ed. James A. Sanders (New York: Doubleday, 1970) 382-394 [chronol.].

GOETZE: J. J. Finkelstein, 'Bibliography of Albrecht Goetze (1897-1973)', JournaJ. of Cuneiform Studies 26 (1974) 2-15 [classif.].

GOGUEL: 'Travaux de Maurice Goguel', Coniectanea Neotestamentica 10 (1946) 5-12 [classif.].

GOODENOUGH: A. Thomas Kraabel, 'A Bibliography of the Writings of Erwin Ramsdell Goodenough', Religions in Antiquity. Essays in Memory of Erwin Ramsdell Goodenough, ed. Jacob Neusner (Leiden: Brill, 1968) 621-632 [chronol.]. 
GOODSPEED: 'A List of the Publications of Edgar J. Goodspeed', James I. Cook, Edgar Johnson Goodspeed, Articulate Scholar (Chico: Scholars Press, 1981) 81-88 [classif., not reviews].

GORE: 'Works by Charles Gore', Colin Brown in Creative Minds in Contemporary Theology, ed. P. E. Hughes (Grand Rapids: Eerdmans, 1966) 375-376 [chronol.].

GUNKEL: Johannes Hempel, 'Hermann Gunkels Bücher und Schriften', EYXAPIETHPION. Studien zur Religion und Literatur des Alten und Neuen Testaments, Hermann Gunkel zum 60 Geburtstage...dargebracht ...., ed. Hans Schmidt (Göttingen: Vandenhoeck and Ruprecht, 1923), II. 'Zur Religion und Literatur des Neuen Testaments', 214-225 [chronol.].

HAENCHEN: Ute Eichelberg and Volkhart Lorentzen, 'Verzeichnis der Veröffentlichungen von Ernst Haenchen', Apophoreta. Festschrift für Ernst Haenchen zu seinem siebzigsten Geburtstag, ed. W. Eltester and F. H. Kettler (Berlin: Alfred Töpelmann, 1964) 1-6 [chronol.].

HAMMERSHAIMB: Knud Jeppesen, 'Bibliography of $\mathbf{E}$. Hammershaimb', VT 24 (1974) 244-249 [classif.].

HARDER: Christian Bartsch, 'Bibliographie Günther Harder', Treue zur Thora. Beiträge zur Mitte des christlich-jüdischen Gesprächs. Festschrift für Gïnther Harder zum 75. Geburtstag, ed. Peter von der Osten-Sacken (Berlin: Institut Kirche und Judentum, 1977) 207-220 [classif.].

HARRISON, E. F.: 'Bibliography', Scripture, Tradition and Interpretation. Essays Presented to Everett $F$. Harrison... in Honor of his Seventy-fifth Birthday, ed. W. W. Gasque and W. S. Lasor (Grand Rapids: Eerdmans, 1978) 313-319 [chronol.].

HERTZBERG: Andreas Hertzberg, 'Opera', Gottes Wort und Gottes Land. Hans-Wilhelm Hertzberg zum 70. Geburtstag...dargebracht..., ed. Henning Graf Reventlow (Göttingen: Vandenhoeck and Ruprecht, 1965) 221-228 [classif.].

HILGENFELD: 'Adolf Hilgenfeld', Horton Harris, The Tübingen School (Oxford: Clarendon Press, 1975) 280282 [brief, ref. to letters].

HOLTZ: Matthias Kleiminger, 'Bibliographie Gottfried Holtz', TLZ 104 (1979) 472-473 Iclassif., some reviews; cf. TLZ 94 (1969) 153-158]. 
HOOKE: 'Principal Works of Professor S. H. Hooke', Promise and Fulfilment. Essays Presented to Professor S. H. Hooke, ed. F. F. Bruce (Edinburgh: T. and T. Clark, 1963) 213-214.

HYATT: 'Bibliography', Essays in old Testament Ethics (J. Philip Hyatt. In Memoriam), ed. James I. Crenshaw and John T. Willis (New York: KTAV, 1974) xi-xxxi [classif.].

IWAND: Dieter Pauly in Evangelische Theologie 41 (1981) 181-183 [suppl. and corrections; cf. TLZ 85 (1.960) 877 $-880]$.

JACOBSEN: 'Bibliography', Thorkild Jacobsen, Toward the Image of Tammuz and Other Essays in Mesopotamian History and Culture, ed. William L. Moran (Cambridge, Mass.: Harvard UP, 1970) 471-474 [classif.], with lexical index 475-487.

JAMES: 'A List of the Principal Published Writings of E. O. James', The Saviour God. Comparative Studies in the Concept of Salvation Presented to Edwin Oliver James..., ed. S. G. F. Brandon (Manchester UP, 1963) xiii-xxi [chronol.].

JEPSEN: Julia Mănnchen, 'Bibliographie Alfred Jepsen', TLZ 105 (1980) 798-800 classif., cf. TLZ 95 (1970) 552-554].

JEREMIAS: 'Bibliographie Joachim Jeremias 1923-1970', Der Ruf Jesu und die Antwort der Gemeinde.

Exegetische Untersuchungen Joachim Jeremias zum 70. Geburtstag gewidmet..., ed. E. Lohse, C. Burchard and B. Schaller (Göttingen: Vandenhoeck and Ruprecht, 1970) 11-38 [chronol., with classified index].

JOHNSON: 'Bibliography: Writings of Sherman E. Johnson', Gospel Studies in Honor of Sherman Elbridge Johnson (ATR Supp. 3, 1974), ed. Massey H. Shepherd Jr. and Edward C. Hobbs, 126-134 [classif.].

JONAS: 'Bibliographie Hans Jonas', Gnosis. Festschrift für Hans Jonas, ed. Barbara Aland et al. (Gottingen: Vandenhoeck and Ruprecht, 1978) 508-514 [chronol.].

JONES: 'Books and Articles by Tom B. Jones', Studies in Honor of Tom B. Jones, ed. Marvin A. Powell and Ronald H. Sack ( $A O A T$ 20) (Neukirchen-Vluyn: Neukirchener Verlag, 1979) 347-352 [classif.]. 
KÄHLER: Martin Rohkrämer, 'Bibliographie Ernst Kähler', TLZ 104 (1979) 474-477 [classif.].

KÄSEMANN: (1) Friedrich Gustav Lang, 'Bibliographie Ernst Käsemann 1933-1975', Rechtfertigung. Festschrift für Ernst Käsemann zum 70. Geburtstag, ed. Johannes Friedrich, Wolfgang Pöhlmann and Peter stuhlmacher (Tübingen: J. C. B. Mohr and Göttingen: Vandenhoeck and Ruprecht, 1976) 593-604 [chronol.].

(2) 'Oeuvres de Ernst Kaesemann', Pierre Gisel, Vérité et histoire. La théologie dans la modernité: Ernst Käsemann (Paris: Beauchesne and Genève: Labor et Fides, 1977) 13-15 [select].

KAUFMANN: ביבליוןגרפיה, Yehezkel Kaufmann Jubilee Volume. Studies in Bible and Jewish Religion dedicated to Yehezkel Kaufmann on the occasion of his seventieth birthday, ed. Menahem Haran (Jerusalem: Magnes Press, 1960) א [classif.].

KENYON: N. J. H. Lord and A. C. Western, 'A Bibliography of kathleen M. Kenyon up to 1975', Archaeology in the Levant. Essays for Kathleen Kenyon, ed. Roger Moorey and Peter Parr (Warminster: Aris and Phillips, 1978) xi-xiv [classif.].

KILPATRICK: 'Bibliography of the Writings of George Kilpatrick 1939-1974', Studies in New Testament Language and Text. Essays in Honour of George $D$. Kilpatrick on the Occasion of his Sixty-fifth Birthday (Nov.T. Supp. 44), ed. J. K. Elliott (Leiden: Brill, 1976) 4-13 [classif.].

KNOX: John Coolidge Hurd, Jr., 'Bibliography of the Work of John Knox', Christian History and Interpretation. Studies Presented to John Knox, ed. W. R. Farmer, C. F. D. Moule and R. R. Niebuhr (Cambridge UP, 1967) xxiii-xxxii [chronol., not reviews, but incl. bibliography of reactions to his work].

KÖBERLE: Gotthold Müller, 'Bibliographie Adolf Köberle 1958-1974', TLZ 100 (1975) 473-480 [classif.].

KOSMALA: 'Bibliography Hans Kosmala', Annual of the Swedish Theological Institute 9 (1973) 5-13 [chronol.].

KöSTLIN: 'Karl Reinhold Köstlin', Horton Harris, The Tübingen School (Oxford: Clarendon Press, 1975) 279280 [brief, ref. to letters]. 
KRAMER: 'Bibliography of the Writings of Samuel Noah Kramer', Kramer Anniversary Volume. Cuneiform Studies in Honor of Samuel Noah Kramer, ed. Barry L. Eichler et al. ( $A O A T$ 25) (Neukirchen-Vluyn: Neukirchener Verlag, 1976) 451-461 [classif.].

KÜMMEL: (1) 'Bibliographie 1929-1964', Werner Georg Kümmel, Heilsgeschehen und Geschichte. Gesammelte Aufsätze 1933-1964, ed. Erich Grässer, Otto Merk and Adolf Fritz (Marburg: N. G. Elwert Verlag, 1965) 471482 [chronol.].

(2) 'Bibliographie 1965-1978', op. cit. Vol. 2, Gesammelte Aufsätze 1965-1976, ed. E. Grässer and 0. Merk, 261-266 [chronol.].

KUYPER, A.: 'Werken van A. Kuyper', W. H. Velema, De Leer van de Heilige Geist bij Abraham Kuyper

('s-Gravenhage: Keulen, 1957) 247-249 [books only, alphab.] .

KUYPER, L. J.: 'A Bibliography of the Writings of Lester J. Kuyper', Grace upon Grace. Essays in Honor of Lester J. Kuyper, ed. James I. Cook (Grand Rapids: Eerdmans, 1975) 153-154 [classif., not reviews].

LABIB: Victor Girges, 'A Bibliography of the Books and Articles of Pahor Labib', Essays on the Nag Hammadi Texts. In Honour of Pahor Labib, ed. Martin Krause (Leiden: Brill, 1975) 4-8 [chronol.].

LADD: 'A Select Bibliography of George Eldon Ladd', Unity and Diversity in New Testament Theology. Essays in Honor of George Eldon Ladd, ed. Robert A. Guelich (Eerdmans: Grand Rapids, 1978) 214-217 [chronol., not reviews].

LAGRANGE: L.-H. Vincent, 'Essai d'une bibliographie sommaire du Père Lagrange', Mémorial Lagrange, ed. L.-H. Vincent (Paris: Gabalda, 1940) [classif., not reviews].

LANDSBERGER: (1) 'B. Landsberger's Lexicographical Contributions', Journal of Cuneiform Studies 4 (1950) 3-62 [classif., with index].

(2) Anne Draffkorn Kilmer and Johannes Renger, 'A Bibliography of B. Landsberger's Works', J.Cun.Stud. 26 (1974) 183-194 [classif.]. 
LANDSBERGER: (3) Daniel A. Foxvog and Anne Draffkorn Kilmer Berkeley, 'Benno Landsberger's Lexicographical Contributions', J.Cun.Stud. 27 (1975) 3-126 [words alphabetically, classified by languages].

IANG: Joachim Miltenberger, 'Bibliographie Friedrich Lang', TLZ 104 (1979) 541-544 [classif., not reviews].

LAPP: (1) 'Bibliography of Paul W. Lapp', HTR 64 (1971) 131-134 [chronol.].

(2) 'Bibliography of Paul w. Lapp', The Tale of the Tell. Archaeological Studies by Paul W. Lapp, ed. Nancy L. Lapp (Pittsburgh Theological Monograph Series 5 (Pittsburgh: Pickwick Press, 1975) 128-133 [chronol.].

LASOR: Dawn E. Waring, 'A Select Bibliography of the Writings of William Sanford.LaSor', Biblical and Near Eastern Studies. Essays in Honor of William Sanford LaSor, ed. Gary A. Tuttle (Grand Rapids: Eerdmans, 1978) 276-282 [classif.].

LAST: (Margerie Venables Taylor), 'Bibliography of the Published Writings of H. M. Last', JRS 47 (1957) 3-8 [chronol.].

LAU: Ingemaren Brüschke, 'Bibliographie Franz Lau', TLZ 97 (1972) 153-155 [classif., cf. TLZ 92 (1967) 141154].

LEENHARDT: 'Bibliographie de Franz-J. Leenhardt', L'Fvangile hier et aujourd'hui. Mélanges offerts au Professeur Franz-J. Leenhardt (Genève: Editions Labor et Fides, 1968) 293-296 [chronol., not reviews].

LEHMANN: Rudolf Göbel, 'Ausgewählte Bibliographie Arno Lehmann', TLZ 96 (1971) 628-630 [classif., Cf. TLZ 91 (1966) 385-388].

LOSSKY: 'Bibliography of Writings of Vladimir N. Lossky (1903-1958)', Vladimir Lossky, In the Image and Likeness of God, ed. John H. Erickson and Thomas E. Bird (London and Oxford: Mowbray, 1975) 229-232 [classif., not reviews].

MCKENZIE: Donald H. Wimmer and Harry M. Culkin, 'A Bibliography of the Books, Articles and Reviews of John L. McKenzie', No Famine in the Land. Studies in Honor of John L. MCKenzie, ed. James W. Flanagan and Anita Weisbrod Robinson (Missoula: Scholars Press, 1975) 301-322 [chronol.]. 
MANSON, T. W.: 'Select Bibliography of the Works of T. W. Manson', New Testament Essays. Studies in Memory of Thomas Walter Manson 1893-1958, ed. A. J. B. Higgins (Manchester UP, 1959) xi-xiv [chronol., incl. some reviews].

MARCUS: 'Bibliography of Ralph Marcus', Biblical Research 3 (1958) 44-46 [classif., not reviews].

MARTIN, W. J.: (A. R. M.), A Bibliography of William James Martin (1904-1980), 3 pp. [chronol., unpublished].

MAURICE: 'Bibliography of Works by F. D. Maurice', Alec R. Vidlex, The Theology of F. D. Maurice (London: SCM, 1948) 234-238 [books only, chronol.].

MAY: 'Bibliography of Publications of Herbert Gordon May', Translating and Understanding the old Testament. Essays in Honor of Herbert Gordon May, ed. Harry Thomas Frank and William L. Reed (Nashville and New York: Abingdon, 1970) 13-24 [classif.].

MEYER: (1) Waltraut Bernhardt, 'Bibliographie Rudolf Meyer', TLZ 99 (1974) 718 [classif., cf. TLZ 94 (1969) 633-638].

- (2) W. Bernhardt, 'Bibliographie Rudolf Meyer', TLZ 104 (1979) 781-782 [classif.].

MICHEL: (1) Peter Schmidt, 'Bibliographie der Schriften Otto Michels', Abraham unser Vater. Juden und Christen im Gespräch über die Bibel. Festschrift für Otto Michel zum 60. Geburtstag, ed. Otto Betz, Martin Hengel and Peter Schmidt (Leiden: Brill, 1963) 484497 [chronol.].

(2) Klaus Haacker, 'Bibliographie der Schriften Otto Michels 1963-1973', Josephus-Studien. Untersuchungen $\mathrm{zu}$ Josephus, dem antiken Judentum und dem Neuen Testament. otto Michel zum 70. Geburtstag gewidmet, ed. Otto Betz, Klaus Haacker and Martin Hengel (Göttingen: Vandenhoeck and Ruprecht, 1974) 370-373 [chronol.].

MORIARTY: Michael A. Fahey, 'Frederick L. Moriarty, S.J. Bibliography', The word in the World. Essays in honor of Frederick L. Moriarty, S.J., ed. Richard J. Clifford and George W. MacRae (Cambridge, Mass.: Weston College Press, 1973) 271-282 [chronol.]. 
MORRIS: David Williams, 'A Select Bibliography of the Writings of L. L. Morris', Reconciliation and Hope. New Testament Essays on Atonement and Eschatology presented to L. L. Morris on his 60th Birthday, ed. Robert Banks (Exeter: Paternoster, 1974) 15-20

[chronol., not reviews].

MOULE: 'Bibliography of the Works of C. F. D. Mou.le', Christ and spirit in the New Testament. Studies in Honour of Charles Francis Digby Moule, ed. Barnabas Lindars and Stephen S. Smalley (Cambridge UP, 1973) $\mathrm{x}-\mathrm{xvi}$ [chronol., not reviews].

MUILENBURG: (1) R. Lansing Hicks, 'A Bibliography of James Muilenburg's Writings', Israel's Prophetic Heritage. Essays in honor of James Muilenburg, ed. Bernhard W. Anderson and Walter Harrelson (London: SCM, 1962) 233-242 [classif.].

(2) Ivan Jay Ball, Jr., 'Additions to a Bibliography of James Muilenburg's Writings', Rhetorical Criticism. Essays in Honor of James Muilenburg, ed. Jared J. Jackson and Martin Kessler (Pittsburgh: Pickwick Press, 1974) 285-287 [classif.].

MYERS: Carey A. Moore, 'Bibliography of Jacob Martin Myers', A Light unto my Path. old Testament Studies in honor of Jacob M. Myers, ed. Howard N. Bream, Ralph D. Heim and Carey A. Moore (Gettysburg Theological Studies 4) (Philadelphia: Temple University Press, 1974) 521-529 [chronol.].

NAGEL: Reimund Blühm, 'Bibliographie William Nagel', TLZ 101 (1976) 235-240 [classif., reviews summarised].

NIEBUHR: 'Works by Reinhold Niebuhr', Theodore Minnema in Creative Minds in Contemporary Theology, ed. P. E. Hughes (Grand Rapids: Eerdmans, 1966) 406 [select, chronol.].

NILSSON: 'Martin P:son Nilsson's Contributions to the Review', HTR 60 (1967) 373 [HTR only].

NOACK: Jakob H. Grфnbaek, 'Bent Noack-bibliografi 19431975', Hilsen til Noack. Fra kolleger og medarbejdere til Bent Noack på 60- ărsdagen...., ed. Niels Hyldahl and Eduard Nielsen (Kфbenhavn: G. E. C. Gad, 1975) 228-232 [chronol., not reviews].

NOCK: 'Bibliographica. Bibliography of the Published Writings of Arthur Darby Nock', Arthur Darby Nock, Essays on Religion and the Ancient World, 2 vols., ed. Zeph Stewart (Oxford: Clarendon Press, 1972) II 966-900 [chronol., with index]. 
NOTH: Hermann Schult, 'Bibliographie Martin Noth', Martin Noth, Gesammelte Studien zum Alten Testament II (Theologische Bücherei 39) ed. Hans Walter Wolff (Mïnchen: Chr. Kaiser Verlag, 1969) 166-205 [classif.].

NÖTSCHER: G. Johannes Botterweck, 'Friedrich Nötschers Schriften', Alttestamentliche Studien Friedrich Nötscher zum 60. Geburtstag gewidmet... (Bonner Biblische Beiträge 1), ed. Hubert Junker and Johannes Botterweck (Bonn: Peter Hanstein Verlag, 1950) 289292 [classif.].

ONASCH: Friederike Köckert and Hermann Goltz, 'Bibliographie Konrad Onasch', TLZ 106 (1981) 613-622 [classif.].

OUDERSLUYS: 'A Bibliography of the Writings of Richard C. Oudersluys', Saved by Hope. Essays in Honor of Richard C. Oudersluys, ed. James I. Cook (Grand Rapids: Eerdmans, 1978) 185-188 [classif.].

PANNENBERG: 'A Bibliography of the Writings of Wolfhart Pannenberg', E. Frank Tupper, The Theology of Wolfhart Pannenberg (London: SCM, 1974) 307-316 [alphab., some reviews].

PEAKE: 'Select Bibliography of Dr. A. S. Peake's Printed Works', Arthur Samuel Peake 1865-1929. Essays in Commemoration, ed. John T. Wilkinson (London: Epworth, 1958) 161-167 [chronol.].

PERRIN: 'Bibliography of the Works of Norman Perrin', Christology and a Modern Pilgrimage. A Discussion with Norman Perrin, ed. Hans Dieter Betz (Society of Biblical Literature, 1971) 153-157 [classif.].

PESCHKE: Helmut Obst, 'Bibliographie Erhard Peschke', TLZ 97 (1972) 476-477 [classif., not reviews].

PIPER: 'A Bibliography of Books and Articles by Otto A. Piper', Current Issues in New Testament Interpretation. Essays in honor of otto A. Piper, ed. William Klassen and Graydon F. Snyder (London: SCM, 1962), 247-260 [classif., not reviews].

PLANCK: 'Karl Christian Planck', Horton Harris, The Tübingen School (Oxford: Clarendon Press, 1975) 278279 [brief, ref. to letters].

POLOTSKY: 'A Bibliography of Writings by $\mathrm{H}$. J. Polotsky', Studies in Egyptology and Linguistics in Honour of H. J. Polotsky, ed. H. B. Rosén (Jerusalem: Israel Exploration Society, 1964) ix-xi [chronol.]. 
PRADO: 'Producción literaria del P. Juan Prado', Homenaje a Juan Prado. Miscelanea de estudios biblicos y hebraicos, ed. L. Alvarez Verdes and E. J. Alonso Hernandez (Madrid: Instituto "Benito Arias Montano", 1975) 29-40 [classif.].

PURDY: 'A Bibliography of the Writings of Alexander C. Purdy, New Testament Sidelights. Essays in Honor of Alexander Converse Purdy, ed. Harvey K. McArthur (Hartford, Conn.: Hartford Seminary Foundation Press, 1960) 129-135 [classif.].

QUASTEN: Patrick Granfield, 'A Bibliography of the Writings of Johannes Quasten', Kyriakon. Festschrift Johannes Quasten, 2 vols., ed. Patrick Granfield and Josef A. Jungmann (Münster: Verlag Aschendorff, 1970) II 924-938 [chronol.].

QUELL: Theodora Hess, 'Bibliographie Gottfried Quell', TLZ 96 (1971) 631-632 [chronol., not reviews].

RAMSAY: (1) A. Margaret Ramsay, 'A List of the Published Writings of Sir William Mitchell Ramsay', Anatolian Studies Presented to Sir William Mitchell Ramsay, ed. W. H. Buckler and W. M. Calder (Manchester UP, 1923) xiii-xxxviii [chronol.].

(2) 'A Chronological List of Ramsay's Major Works', W. W. Gasque, Sir William M. Ramsay, Archaeologist and New Testament Scholar. A Survey of his Contribution to the Study of the New Testament (Baker Studies in Biblical Archaeology) (Grand Rapids: Baker Book House, 1966) 66-77 [incl. indexes].

(3) C. J. Hemer, 'The Later Ramsay. A Supplementary Bibliography of the Published Writings of Sir William Mitchell Ramsay', TynB 22 (1971) 119-124.

RAPP: Otto Böcher, 'Bibliographie Eugen Ludwig Rapp 1964-1973', TLZ 100 (1975) 555-558 [chronol., cf. TLZ 90 (1965) 151-158].

RICOEUR: (1) Loretta Dornisch, 'Paul Ricoeur and Biblical Interpretation. A Selected Bibliography', Semeia 4 (1975) 23-26 [classif.].

(2) Loretta Dornisch, 'Paul Ricoeur and Biblical Interpretation. A Selected Bibliography II', Semeia 19 (1981) 23-27 [chronol.].

RIGAUX: 'Bibliographie du R. P. Béda Rigaux', Mélanges bibliques en hommage au R. P. Béda Rigaux, ed. A. Descamps and A. de Halleux (Gembloux: Duculot, 1970) xxiii-xxviii [chronol.]. 
RINALDI: F. Luciani, 'Bibliografia del P. G. Rinaldi', Studi sull' Oriente e la Bibbia, offerti al $P$. Giovanni Rinaldi nel $60^{\circ}$ compleanno... (Genova: Editrice Studio e Vita, 1967) 381-385 [classif., reviews not detailed].

RITSCHL: 'Albrecht Ritschl', Horton Harris, The Tübingen School (Oxford: Clarendon Press, 1975) 280 [brief, ref. to letters].

ROBERT: Joseph Trinquet, 'Bibliographie de M. André Robert', Mélanges bibliques rédigés en honneur de André Robert (? Paris: Bloud et Gay, n.d.) 5-10 [chronol.].

ROBERTS: Gwilym H. Jones, 'Cyhoeddiadau'r Athro Bleddyn J. Roberts', Efrydiau Beiblaidd Bangor. Cyfrol Deyrnged i'r Athro Bleddyn Jones Roberts, ed. D. R. Ap-Thomas (Abertawe [Swansea] : John Penry, 1973) xvii$\mathrm{xx}$ [chronol., not reviews].

ROBERTSON: 'Bibliography of the Published Writings of the Reverend James Robertson, D.D., LL.D.', Studia Semitica et orientalia, by seven members of Glasgow University Oriental Society (Glasgow: McLehose, Jackson \& Co., 1920) 126-127 [chronol., select, some reviews].

ROBINSON, H. WHEELER: E. A. Payne, 'A Bibliography of the Writings of Dr. H. Wheeler Robinson', Studies in History and Religion Presented to Dr. H. Wheeler Robinson, M.A., on his seventieth birthday, ed. E. A. Payne (London and Redhill: Lutterworth, 1942) 254257 [chronol., not reviews].

ROBINSON, T. H.: G. Henton Davies, 'A Bibliography of the Writings of Theodore Henry Robinson', Studies in old Testament Prophecy Presented to Professor Theodore H. Robinson, ed. H. H. Rowley (Edinburgh: T. and T. Clark, 1950) 201-206 [chronol., not reviews].

ROBINSON, W. C.: 'Publications', Soli Deo Gloria. New Testament studies in Honor of William Childs Robinson, ed. J. McDowell Richards (Richmond, Virginia: John Knox Press, 1968) 138-140 [classif., not reviews].

ROOKMAAKER: 'Publications by H. R. Rookmaaker', Linette Martin, Hans Rookmaaker. A Biography (London: Hodder, 1979) 183 [books only]. 
ROST: (1) D. Kellermann, 'Bibliographie Leonhard Rost', Das Ferne und Nahe Wort. Festschrift Leonhard Rost zur Vollendung seines 70. Lebensjahres..,gewidmet, ed. Fritz Maas (Berlin: Alfred Töpelmann, 1967) 265275 [classif.].

(2) Mechthild and Dieter Kellermann, 'Bibliographie Leonhard Rost', TLZ 97 (1972) 77-80 [Classif., Cf. TLZ 81 (1956) 697-702 and 87 (1962) 151-154].

(3) Mechthild Kellermann, 'Bibliographie Leonhard Rost', TLZ 101 (1976) 878-880 [classif] .

ROWLEY: G. Henton Davies, 'Select Bibliography of the Writings of Harold Henry Rowley', Wisdom in Israel and in the Ancient Near East, presented to Harold Henry Rowley, ed. M. Noth and D. Winton Thomas (VT Supp. 3) Leiden: Brill, 1955) xi-xix [chronol.].

RYLAARSDAM: Arthur L. Merrill, 'The Writings of J. Coert Rylaarsdam', Scripture in History and Theology. Essays in honor of $\mathrm{J}$. Coert Rylaarsdam, ed. A. L. Merrill and Thomas $\mathrm{W}$. Overholt (Pittsburgh: Pickwick Press, 1977) 391-396 [classif., not reviews].

SANDAY: A. Souter, 'A Bibliography of Dr. Sanday', JTS 22 (1921) 193-205 [chronol.].

SAUER: Christa Antensteiner, 'Bibliographie F. Sauer', Memoria Jerusalem. Freundesgabe Franz Sauer zum 70. Geburtstag, ed. Johannes B. Bauer and Johannes Marböck (Graz: Akademische Druck-u-Verlagsanstalt, 1977) 237-238 [brief, not reviews].

SCHICK: 'Schriftenverzeichnis', Kirche und Bibel. Festgabe für Bischof Eduard Schick, ed. Professors of Phil-Theol. Hochschule Fulda (Paderborn etc.: Ferdinand Schöningk, 1979) 501-502 [classif.].

SCHMID: Paul Neuenzeit, 'Bibliographie Josef Schmid', Neutestamentliche Aufsätze. Festschrift für Prof. Josef Schmid zum 70. Geburtstag, ed. J. Blinzler, 0. Kuss and F. Mussner (Regensburg: Verlag Friedrich Pustet, 1963) 311-317 [classif.].

SCHOTT: M. Müller and A. Lischke, 'Bibliographie Erdmann Schott', TLZ 96 (1971) 77-80 [classif., cf. TLZ 86 (1961) 393-398; 90 (1965) 955-958].

SCHÜRMANN: C.-P. März, 'Bibliographie Heinz Schürmann. Veröffentlichungen seit 1949', Die Kirche des Anfangs. Für Heinz Schürmann, ed. Rudolf Schnackenburg, Josef Ernst and Joachim Wanke 
(Freiburg, Basel and Wien: Herder, 1978) 633-658 [chronol.].

SCHWEGLER: 'Albert Schwegler', Horton Harris, The Tübingen School (Oxford: Clarendon Press, 1975) 278 [brief, ref. to letters].

SEVENSTER, G.: H. van der Kwaak, 'A Bibliography of Prof. Dr. G. Sevenster', NovT 8 (1966) 301-307 [classif.].

SEVENSTER, J. N.: M. C. Rientsma, 'A Bibliography of Prof. Dr. J. N. Sevenster', Studies in John presented to Professor Dr. J. N. Sevenster on the occasion of his seventieth birthday (NovT Supp. 24) Leiden: Brill, 1970) 1-11 [classif.].

SILVER: Miriam Leikind, 'A Bibliography of the Writings of Abba Hillel Silver', In the Time of Harvest. Essays in Honor of Abba Hillel Silver on the occasion of his 7oth birthday, ed. Daniel Jeremy Silver (New York: Macmillan, and London: Collier-Macmillan, 1963) 99-120 [classif.].

SIMON: 'Publications de Marcel Simon', Paganisme, Judaïsme, Christianisme. Mélanges offerts à Marcel Simon. Influences et affrontements dans le monde antique, ed. A. Benoit, M. Philonenko and C. Vogel (Paris: E. de Boccard, 1978) 371-387 [chronol.].

SOMMERLATH: 'Nachtrag zur Bibliographie Ernst Sommerlath', TLZ 99 (1974) 78 [Cf. TLZ 74 (1949) 49-50; 84

. (1959) 73-74; 89 (1964) 153-154; 94 (1969) 75-76].

SPEISER: 'Bibliography of the Writings of Ephraim Avigdor Speiser', Oriental and Biblical studies. Collected Writings of E. A. Speiser, ed. J. J. Finkelstein and Moshe Greenberg (Philadelphia: University of Pennsylvania Press, 1967) 587-603 [classif.].

SPURGEON: 'Schriften von Spurgeon', Peter Spangenberg, Theologie und Glaube bei spurgeon (Gïtersloh: Gerd Mohn, 1969) 187-193 [classif., sermons by subject].

STÄHLIN: Otto Böcher, 'Bibliographie Gustav Stählin', Verborum Veritas. Festschrift für Gustav stählin zum 70. Geburtstag, ed. Otto Böcher and Klaus Haacker (Wuppertal: Rolf Brockhaus, 1970) 375-383 [chronol.]. 
STAMM: J. M. Myers, 'A List of the Writings of Raymond Thomas Stamm', Search the Scriptures. New Testament Studies in Honor of Raymond T. Stamm Gettysburg Theological studies 3), ed. J. M. Myers, O. Reimherr and H. N. Bream (Leiden: Brill, 1969) 1-4 [classif.].

STAUFFER: (Frau) Hanna Stauffer, 'Schriftenverzeichnis Ethelbert Stauffer', JSNT 11 (1981) 21-38 [chronol.].

STINESPRING: 'Bibliography', The Use of the old Testament in the New and other Essays. Studies in Honor of William Franklin Stinespring, ed. James M. Efird (Durham, North Carolina: Duke University Press, 1972) xiv-xv [classif., not reviews].

STRAUSS: 'Strauss' Published Writings', Horton Harris, David Friedrich strauss and his Theology (Cambridge UP, 1973) 287-295 [chronol., also ref. to letters, 285-287].

SUKENIK: U. Ben-Horin, 'Bibliography of the Writings of E. I. Sukenik', E. L. Sukenik Memorial Volume (18891953), ed. N. Avigad, M. Avi-Yonah, H. Z. Hirschberg and B. Mazar (Eretz-Israel. Archaeological, Historical and Geographical Studies 8) (Jerusalem: Israel Exploration Society, 1967) כא-כז [chronol.].

SUMMERS: Glenn O. Hilburn, 'Publications by Ray Summers', New Testament Studies. Essays in Honor of Ray Summers in his sixty-fifth year, ed. Huber I. Drumwright and Curtis Vaughan (Waco,Texas: Baylor UP, 1975) 177-195 [classif.].

SWETE: C. H. Turner and A. Rogers, 'A Bibliography of the Published Works of the Late Henry Barclay Swete', JTS 19 (1918) 1-19 [classif.].

TAYLOR: D. R. Wilson, 'A Bibliography of the Published Writings of Margerie Venables Taylor', JRS 54 (1964) 2-6. [chronol.].

TENNEY: Thomas A. Askew, 'Select Bibliography of the Writings of Merrill C. Tenney, Current Issues in Biblical and Patristic Interpretation. Studies in Honor of Merrill C. Tenney...., ed. Gerald F. Hawthorne (Grand Rapids: Eerdmans, 1975) 19-20 [classif., not reviews]. 
TERRIEN: Bruce E. Nielsen, 'A Bibliography of the Books, Articles and Reviews of Samuel Terrien', Israelite Wisdom: Theological and Literary Essays in Honor of Samuel Terrien, ed. John G. Gammie, Walter A. Brueggemann, W. Lee Humphreys and James M. Ward (Missoula: Scholars Press, 1978) 15-22 [chronol.].

THOMAS: (1) Anthony Phillips, 'Bibliography of the Writings of David Winton Thomas', Words and Meanings, Essays Presented to David Winton Thomas on his retirement..., ed. Peter R. Ackroyd and Barnabas Lindars (Cambridge UP, 1968) 217-228 [chronol.].

(2) Anthony Phillips, 'Additional Bibliography of the Writings of David Winton Thomas', VT 22 (1972) 105-106 [chronol.].

TILLICH: (1) Kenneth Hamilton, 'Books/Articles by Paul Tillich in English', Creative Minds in Contemporary Theology, ed. Philip Edgcumbe Hughes (Grand Rapids: Eerdmans, 1966) 480-481 [classif.].

(2) 'Bibliography', John R. Stumme, Socialism in Theological Perspective. A Study of Paul Tillich 1918-1933 (Missoula: Scholars Press, 1978) 271-283 [essentially chronol., not reviews].

(3) 'Bibliography. (i) Works of Tillich', Adrian Thatcher, The Ontology of Paul Tillich (Oxford UP, 1978) 178-180 [alphab., not reviews].

TORRANCE: Bryan Gray, 'Bibliography of the Published Writings of Thomas F. Torrance (1941-1975)', Creation, Christ and Culture. Studies in Honour of T. F. Torrance, ed. Richard W. A. McKinney (Edinburgh: T. and T. Clark, 1976) 307-321 [chronol.].

TüCHLE: 'Verzeichnis der Veröffentlichungen von Hermann Tüchle', Konzil und Papst. Historische Beiträge zur Frage der höchsten Gewalt in der Kirche. Festgabe für Hermann Tüchle, ed. Georg Schwaiger (München, Paderborn and Wien: Ferdinand Schöningk, 1975) 679-687 687 [classif., reviews summarised].

URNER: 'Bibliographie Hans Unner', TLZ 97 (1972) 397398 [classif., cf. TLZ 86 (1961) 871-876 and 91 (1966) 389-390].

VAN SELMS: 'Publications by A. van Selms', De Fructu Oris Sui. Essays in Honour of Adrianus van Selms, ed. I. H. Eybers, F. C. Fensham, C. J. Labuschagne, W. C. van Wyk and A. H. van $\mathrm{Zyl}$ (Pretoria Oriental Studies 9) (Leiden: Brill, 1970) 252-259 [classif.]. 
VAN TIL: 'Writings of Cornelius van Til', Jerusalem and Athens. Critical Discussions on the Philosophy and Apologetics of Cornelius van Til, ed. E. R. Geehan (Nutley, NJ: Presbyterian and Reformed, 1971) 492-498 [classif.].

VISSER 'T HOOFT: 'Bibliography', Franç่ois C. Gérard, The Future of the Church. The theology of renewal of Willem Adolf Visser 't Hooft (Pittsburgh Theological Monograph Series 2) (Pittsburgh: Pickwick Press, 1974) 232-236 [classif., not reviews].

VOGEL: Traugott Vogel, 'Bibliographie Heinrich Vogel', TLZ 97 (1972) 793-796 [classif., not reviews; cf. TLZ 87 (1962) 471-476 and Vom Herrengeheimnis der Wahrheit. Festschrift..., ed. Kurt Scharf, Berlin and Stuttgart, 1962 - not verified].

VOIGT: (1) Gerhard Graf, 'Bibliographie Gottfried Voigt', TLZ 99 (1974) 874-880 [classif.].

(2) Gerhard Graf, 'Bibliographie Gottfried Voigt', TLZ 104 (1979) 622-624 [classif.].

VOLKMAR: 'Gustav Volkmar', Horton Harris, The Tübingen School (Oxford: Clarendon Press, 1975) 282 [brief, ref. to letters].

VON LOEWENICH: Helmut Merkel and Peter Stimpel, 'Bibliographie Walther von Loewenich 1968-1977', TLZ 103 (1978) 698-702 [chronol., cf. HumanitasChristianitas. Walther von Loewenich zum 65. Geburtstag, ed. Karlmann Beyschlag et al. (Witten, 1968) 384-4l1 - not verified].

VON RAD: Konrad von Rabenau, 'Bibliographie Gerhard von Rad', Probleme biblischer Theologie. Gerhard von Rad zum 70. Geburtstag, ed. Hans Walter Wolff (Munchen: Chr. Kaiser, 1971) 665-681 [classif.].

VON SODEN, H.: Erich Dinkler, 'Bibliographie Hans Freiherr von Soden', Theologische Rundschau 46 (1981) 206-218 [chronol.].

VON SODEN, W.: W. Röllig, 'Schriftenverzeichnis w. von Soden', LiJ̌ān mithurti. Festschrift Wolfram Freiherr von Soden...gewidmet..., ed. W. Röllig (AOAT 1) (Neukirchen-Vluyn: Neukirchener Verlag, 1969) xixxviii [classif.].

Vos: James T. Dennison, Jr., 'A Bibliography of the Writings of Geerhardus Vos (1862-1949)' WTJ 38 (1975-6) 350-367 [chronol., also MS material]. 
VRIEZEN: 'Bibliografie van de voornaamste geschriften van Prof. Dr. Th. C. Vriezen', Studia Biblica et Semitica Theodoro Christiano Vriezen dedicata, ed. W. C. van Unnik and A. S. van der Woude (Wageningen: Veenman, 1966) 13-17 [chronol., some reviews].

WAGNER: Wolfram Böhme and Martin Petzoldt, 'Bibliographie Heinz Wagner', TLZ 103 (1978) 74-77 [classif.].

WARFIELD: 'List of Other Studies in Theology', B. B. Warfield, Studies in Theology (New York, etc.: Oxford UP, 1932) 667-671 [classif., suppl. to those printed in the book].

WEISER: K.-D. Marxmeier and E. Sehmsdorf, 'Bibliographie Artur Weiser', Tradition und Situation. Studien zur alttestamentlichen Prophetie, Artur Weiser zum 70. Geburtstag...dargebracht,..., ed. Ernst Würthwein and Otto Kaiser (Göttingen: Vandenhoeck and Ruprecht, 1963) 153-156 [classif.].

WESTCOTT: 'Appendix III. Bibliographical', Arthur Westcott,. The Life and Letters of Brooke Foss Westcott, D.D., D.C.L., Sometime Bishop of Durham, 2 vols. (London: Macmillan, 1903) II. 441-448 [chronol., not reviews].

WIKGREN: Robert W. Allison, 'Bibliography', studies in New Testament and Early Christian Literature. Essays in Honor of Allen P. Wikgren, ed. David Edward Aune (NovT Supp. 33)(Leiden: Brill, 1972) 253-257 [classif., reviews not detailed].

WILDER: Arthur J. Dewey, 'Amos Niven Wilder. Bibliography', Semeia 13 (1978) 263-286 [classif.].

WILLIAMS, G. H.: Maria Grossmann, 'Towards a Complete Bibliography of the Writings of George Huntston Williams, in honor of his sixtieth birthday', HTR 67 (1974) 139-153 [chronol., not reviews].

WILLOUGHBY: 'Bibliography of Harold R. Willoughby', Early Christian Origins. Studies in honor of Harold $R$. Willoughby, ed. Allen Wikgren (Chicago: Quadrangle Books, 1961) 152-159 [classif.].

WINNETT: Ann Bembenek, 'Bibliography of Professor Winnett's Publications', Studies in the Ancient Palestinian World Presented to Professor $F$. $V$. Winnett, ed. J. W. Wevers and D. B. Redford (Toronto Semitic Texts and Studies 2, University of Toronto Press, 1972) 169-171 [chronol.]. 
WRIGHT: 'The Bibliography of G. Ernest Wright', Magnalia Dei. The Mighty Acts of God. Essays on the Bible and Archaeology in Memory of G. Ernest Wright, ed. Frank Moore Cross, Werner E. Lemke and Patrick D. Miller, Jr. (New York: Doubleday, 1976) 577-593 [chronol.].

WÜRTHWEIN: Rainer Bickert, 'Bibliographie Ernst würthwein', Textgemäss. Aufsätze und Beiträge zur Hermeneutik des Alten Testaments. Festschrift für Ernst würthwein zum 70. Geburtstag, ed. A. H. J. Gunneweg and Otto Kaiser (Göttingen: Vandenhoeck and Ruprecht, 1979) 203-208 [classif.].

YOUNG: J. E. Brueckmann, A Partial Bibliography of the Published Writings of Edward Joseph Young 1907-1968, $14 \mathrm{pp}$. [classif., unpublished].

ZELLER: 'Eduard Zeller', Horton Harris, The Tübingen School (Oxford: Clarendon Press, 1975) 276-277 [brief, ref. to letters].

ZIEGLER: 'Bibliographie Professor Dr. Joseph Ziegler', Wort, Lied und Gottesspruch. Festschrift für Joseph Ziegler, 2 vols., ed. Josef Schreiner (würzburg: Echter Verlag, 1972) II. 257-260 [classif.].

ZIMMERLI: Susanne wüst, 'Bibliographie Walther Zimmerli', Beiträge zur alttestamentlichen Theologie.

. Pestschrift für Walther zimmerli zum 70. Geburtstag, ed. Herbert Donner, Robert Hanhart and Rudolf Smend (Göttingen: Vandenhoeck and Ruprecht, 1977) 559-580 [chronol.].

ZUNTZ: 'Bibliography'. G. Zuntz, Opuscula Selecta: Classica, Hellenistica, Christiana (Manchester UP, 1972) 314-319 [classif.]. 